\title{
Decolorization of reactive dyeing wastewater by ferrous ammonium sulfate hexahydrate
}

\author{
Nghiên cưu khử màu nước thải nhuộm hoạt tính bằng muối sắt II \\ Research article
}

Perng, Yuan-Shing; Bui, Ha-Manh*

Department of Environmental Engineering, Dayeh University, No.168, University Rd., Dacun, Changhua-51591, Taiwan, Republic of China

\begin{abstract}
This paper presents the result of dyeing solution coagulation with the use of ferrous ammonium sulfate hexahydrate (FAS). The examined solution contains two reactive dyes: Black 5 and Blue 19. It has been shown that the efficiency of the dye removal depends on the type of dye, coagulation dosage and the initial $\mathrm{pH}$. Our result showed that the increase of initial $\mathrm{pH}$ up to 12 enhanced the color removal efficiency; the FAS dose was $280 \mathrm{ml}$ (Black 5) and $180 \mathrm{mg} / \mathrm{l}$ (Blue 19) at slow mixing time $(15 \mathrm{~min})$, agitation speed $60 \mathrm{rpm}$, and the initial dye concentration should be 50 and $100 \mathrm{mg} / \mathrm{L}$ for Black 5 and Blue 19, respectively.
\end{abstract}

Chất keo tụ sắt (II) amoni sulfate (FAS) được sủ dụng khủ màu của hai màu nhuộm hoạt tính phổ biến (Blue 19 và Black 5). Kết quả cho thấy, quá trình keo tụ bị ảnh huởng nhiều bởi loại màu nhuộm, nồng độ chất keo tụ và pH của dung dịch đầu vào. Với nồng độ FAS $280 \mathrm{mg} / \mathrm{l}$ (Black 5) và $180 \mathrm{mg} / \mathrm{l}$ (Blue 19), pH đầu vào dung dịch khoảng 12, thời gian phản úng 15 phút, tốc độ khuấy 60 vòng/phút úng với nồng độ màu Black $50 \mathrm{mg} / \mathrm{L}$ và blue $100 \mathrm{mg} / \mathrm{L}$ dung dịch gần nhu mất màu hoàn toàn.

Keywords: color removal, coagulation, dyeing wastewater, reactive Blue 19, reactive Black 5

\section{Introduction}

According to the Vietnam Textile and Apparel Association (VITAS), the textile industry is one of the largest economic sectors in the country. It has 4,000 enterprises with a turnover of 20 billion dollars a year, accounting for $15 \%$ of GDP and making Vietnam the fifth largest textile and garment exporters in the world. However, wastewater effluent from this industry represents a significant environmental problem due to containing synthetic dyes (especially reactive dyes) which are resistant to biodegradation processes (Gottlieb et al., 2003; Sadhasivam et al., 2005).

Various types of wastewater treatment processes that can be used to treat the dye containing wastewater include ozonation, electrocoagulation, adsorption, membrane, sonolysis, etc. (Alinsafi et al., 2005; Kim et al., 2005; Lee et al., 2006). Nonetheless, most of these techniques are limited by methods, costs or difficulties in operation. Hence, they could not be employed to treat real dyeing wastewater.

Coagulation is one of traditional techniques. It normally uses alum or iron-based coagulants such as aluminium, ferrous or ferric chloride, sulphate, poly aluminium chloride $(\mathrm{PAC})$ etc. to destabilize pollutant particles. Thus, the particles are removed by sludge forming. Due to its low cost and convenience, alum-based coagulant is widely used in water and wastewater treatment plants such as for slaughterhouses (Al-Mutairi, 2006), municipal (Guida et al., 2007), even leachates wastewater (Tatsi et al., 2003). However, the coagulants do not seem to be significantly effective on removing organic substances (Shouli et al., 1992). Recently some reports suggest that there may be a possible link between the use of alum-based coagulants and Alzheimer's disease in human (Al-Mutairi, 2006).

Compared to alum-based coagulants, iron-based coagulants have a narrow application for wastewater treatment (Joo et al., 2007). In the other hand, in the fields of dyeing wastewater, iron-based coagulation seems to be more efficient because it uses an optimal $\mathrm{pH}$ for the treatment process, which is around alkaline medium (at effluence $\mathrm{pH}$ of reactive dyeing wastewater) and gives more compact sludge (Arslan, 2001).

In the last few years, a number of studies have focused on iron-based coagulant that completely removed color from dyeing wastewater (Arslan, 2001; Georgiou et al., 2003). 
However, no information was reported about decolorization of reactive dyeing wastewater by ferrous (II) ammonium sulphate hexahydrate (FAS). In addition, there are large numbers of reactive dyes used in dyeing process with difference in "color chromosome". Therefore, the aim of this study is to evaluate the possibility of utilizing FAS for the color removal of two common used reactive dyes, Blue 19 and Black 5, by investigating the influence of the following factors: FAS dosage, initial $\mathrm{pH}$, initial dye concentration, agitation speed, and reaction time in Jar-test experiments.

\section{Materials and methods}

\subsection{Materials}

\subsubsection{Coagulant stock}

FAS were acquired from Guangdong Xilong Chemical Company, Ltd. (China) with bulk density of $1.86 \mathrm{~g} / \mathrm{cm}^{3}$, chemical composition 14\% w/w Fe.

The coagulant stock solution $(10,000 \mathrm{mg} / \mathrm{L})$ was achieved by completely dissolving $1.0 \mathrm{~g}$ FAS powder into $100 \mathrm{~mL}$ distilled water, and the solution was diluted to appropriate concentrations (60 - $320 \mathrm{mg} / \mathrm{L})$ before using.

\subsubsection{Reactive dye stock}

Table 1. Characteristics of used dyes

\begin{tabular}{lcccc}
\hline Dye (C.I. name) & $\mathrm{Mw}(\mathrm{g} \mathrm{mole})$ & $\lambda_{\text {max }}(\mathrm{nm})$ & Molecular structure \\
Reactive Black 5 & 991.82 & 599
\end{tabular}

\section{Results and discussion}

\section{1. $\mathrm{pH}$ influence}

It has been established that $\mathrm{pH}$ plays an important parameter influencing the performance of dye coagulation process (Perng and Bui, 2014). To examine its effect, the sample was adjusted to desired $\mathrm{pH}$ for each experiment by using $0.5 \mathrm{~N} \mathrm{NaOH}$ (or $\mathrm{HCl}$ ) solutions with other constant factors: FAS dosage $120 \mathrm{mg} / \mathrm{L}$, time contact $15 \mathrm{~min}$, agitation speed $60 \mathrm{rpm}$, initial dye concentration (IDC) 100 $\mathrm{mg} / \mathrm{L}$ (Blue 19) and $50 \mathrm{mg} / \mathrm{L}$ (Black 5).

Figure 1 shows the removal efficiency of reactive dye as a function of the initial $\mathrm{pH}$. The maxium removals of Blue 19 and Black 5 were 89.7 and $87.0 \%$ at $\mathrm{pH} 12$, respectively. This result may be due to the formation of $\mathrm{Fe}(\mathrm{OH})_{2}$ (s) flocs which have large surface areas useful for a rapid adsorption of soluble dye as described in Figure 2. At
Reactive Blue 19 (Blue 19) and reactive Black 5 (Black 5) are products of Oh-Young, a Korean company. All dyes were directly used without purification and their characteristics were described in Table 1.

One gram of dyes was directly diluted in 1,000 $\mathrm{ml}$ hot water at $\mathrm{pH} 11$ for an hour to get a dye stock solution of $1,000 \mathrm{mg} / \mathrm{L}$ in the "hydrolyzed" form. Other dye concentrations varying between 10 and $160 \mathrm{mg} / \mathrm{L}$ were obtained by dilution of this stock.

\subsubsection{Procedures}

Coagulation studies were conducted using Jar-Test apparatus (Stuart flocculator sw6) with six beakers (one litter capacity per each), which is based on the ASTM D203513 standard (ASTM, 2013). The effect of $\mathrm{pH}$, reaction time and agitation speed on dye removal were performed by mixing $10 \mathrm{~mL}$ solution containing different FAS dosages with $500 \mathrm{~mL}$ of different dye concentration.

At regular time intervals of coagulation process, samples were collected, filtered and determined the absorbance at suitable wavelengths of maximum absorption $\left(\lambda_{\max }\right)$ given in Table 1 using spectrophotometer UV-VIS GENESYS 10, Thermo Fisher Scientific Inc.

Other water analysis followed standard methods and the results presented here are the mean values \pm standard deviations (SD). other $\mathrm{pH}$, the complexes of formed hydrolysis products caused the decrease of the removal efficiency.

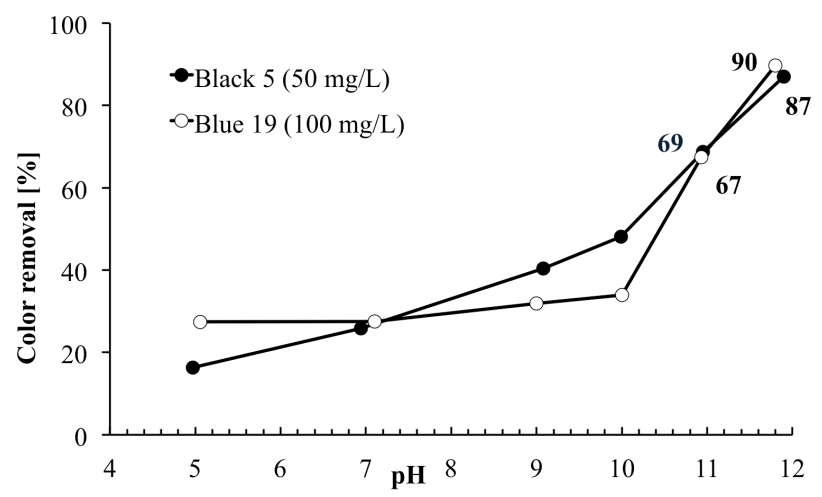

Figure 1. Effect of $\mathrm{pH}$ on dyes color removal (FAS dosage $120 \mathrm{mg} / \mathrm{L}$, agitation speed $60 \mathrm{rpm}$, and time 15 min) 


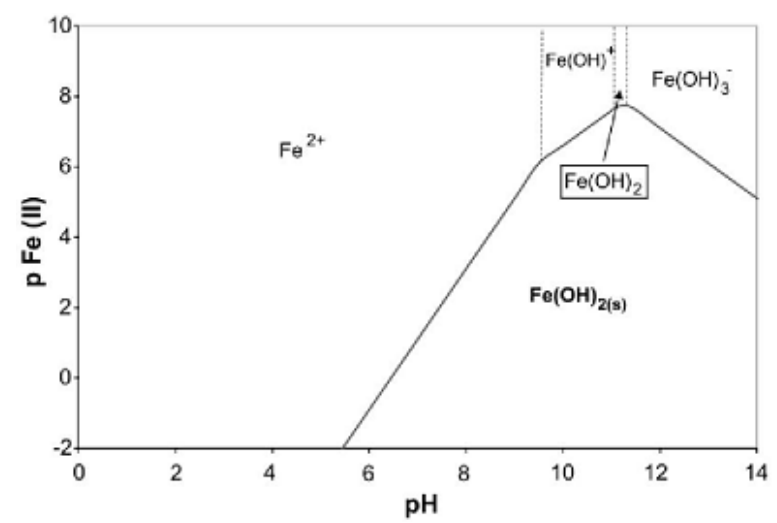

Figure 2. Predominance zone diagram for Fe(II) chemical species in aqueous solution (Carlos et al., 2003)

\subsection{Effect of agitation speed}

As maxium efficiency of color removal was seen at $\mathrm{pH}$ 12 , all further tests were conducted at this $\mathrm{pH}$ value. Tests were conducted at varied speed of stirrers from 30 to 120 rpm in slow mixing phase while maintaining other factors constant, such as the initial dye concentration (100 and 50 $\mathrm{mg} / \mathrm{L}$ for blue and black), FAS dosage $(120 \mathrm{mg} / \mathrm{L})$, and contact time $(15 \mathrm{~min})$. The result is shown in Figure 3.

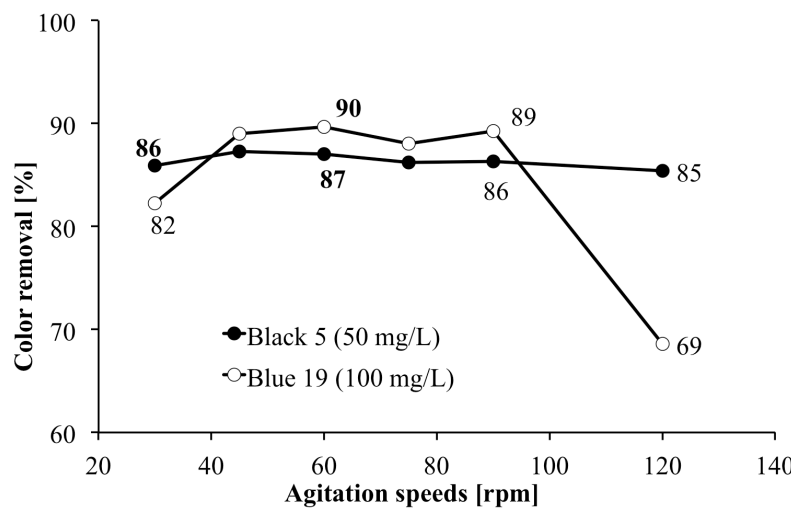

Figure 3. Influence of agitation speed on dye color removal (FAS dosage $120 \mathrm{mg} / \mathrm{L}$, pH 12, and time 15 min)

As can be observed in Figure 3, in the case of Black 5, no significant differences can be stated from these experimental series $\mathrm{Fe}^{2+}$. This result might be caused by the effect of fast soluble rate and fast sludge precipitation rate of the inorganic coagulant with azo bone in Black 5's structure. Thus, any case of agitation speed may be chosen for the next experiment. However, the faster speed requires higher energy costs and the efficiency drop at $120 \mathrm{rpm}$ indicated that the chosen agitation speed for the next experiment should be $60 \mathrm{rpm}$.

For Blue 19, the highest color removal percentage of FAS can be obtained in all dyes solutions with $60 \mathrm{rpm}$ as compared to the other speed. This result corresponds to the agitation speed in the previous report (Tatsi et al., 2003). Hence, the agitation speed of $60 \mathrm{rpm}$ also was chosen for the next study.

\subsection{Effect of slow mixing time}

Along with agitation speed, reaction time at slow mixing phase between coagulant and dye solution also plays relevant role. At this stage, the effect of contact time between FAS and dye solutions was studied by increasing times (15-60 $\mathrm{min})$ under constant parameters at equilibrium condition.

According to Figure 4, with an increase in the contact time, the dye removal efficiency decrease for both dyes. While the significant decrease could be recorded in case of Blue 19, dropped from $89.7 \%$ (15 $\mathrm{min}$ ) to $80.0 \%$ (60 min), the concentration of Black 5 becomes constant or slightly decreases. These results may be due to restabilization phenomenon (Klimiuk et al., 1999). Thus, the appropriate mixing time at slow phase is $15 \mathrm{~min}$.

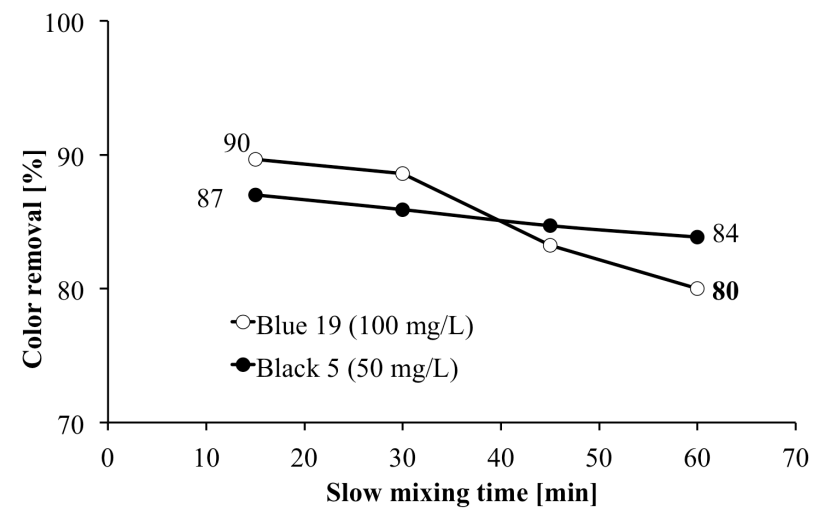

Figure 4. Color removal of studied dyes at various contact time (FAS dosage $120 \mathrm{mg} / \mathrm{L}$, pH 12, and agitation speed $60 \mathrm{rpm}$ )

\subsection{Effect of coagulant dosage}

A series of experiments were conducted to investigate the dependence of color removal on ferrous dosage at constant conditions: optimal pH 12, agitation speed $60 \mathrm{rpm}$, initial dye concentration $50 \mathrm{mg} / \mathrm{L}$ (Black 5) and $100 \mathrm{mg} / \mathrm{L}$ (Blue 19), and contact time $15 \mathrm{~min}$ with different FAS dosage: $60-320 \mathrm{mg} / \mathrm{L}$.

Figure 5 describes that FAS achieved effectiveness for all the dyes. As expected, the increasing in FAS dose had a significant positive impact on the accomplished decolorization. Results show the optimum dose of FAS to be 180 and $280 \mathrm{mg} / \mathrm{L}$ for Blue 19 and Black 5, respectively. The result may explain neutralization mechanism between the positively charged compounds (ferrous hydroxide) with negatively charged colloidal dye particles, and precipitate out.

The results confirm that FAS is the high positive-charged and very effective polymeric for dye removal (Georgiou et al., 2003; Joo et al., 2007). 


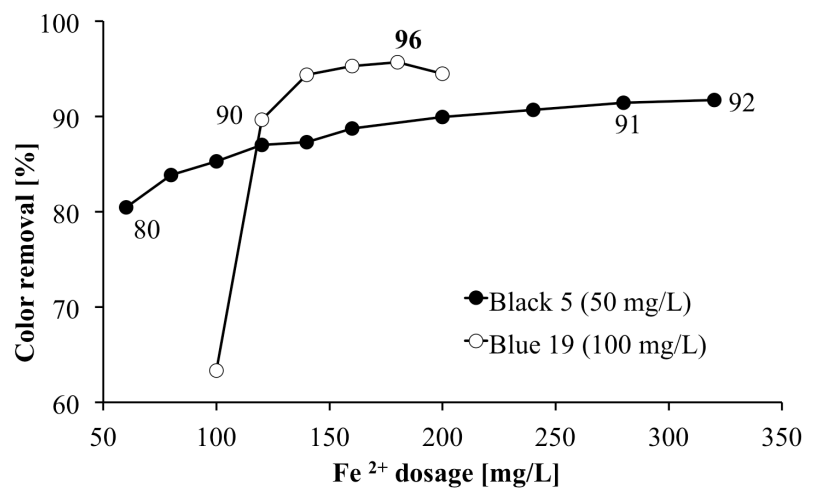

Figure 5. Effect of FAS concentration on dye removal efficiencies (agitation speed $60 \mathrm{rpm}, \mathrm{pH} \mathrm{12}$, and time 15 min)

\subsection{Effect of initial dye concentration}

At this stage, the effect of initial dye concentration (IDC) on decolorization process was performed by increasing concentration (30-140 mg/L) and keeping other parameters constant such as $\mathrm{pH} 12$, agitation speed $60 \mathrm{rpm}$, contact time $15 \mathrm{~min}$, FAS dosage $180 \mathrm{mg} / \mathrm{L}$ for Blue 19 and $280 \mathrm{mg} / \mathrm{L}$ for Black 5.

It is apparent from Figure 6 that with an increase in IDC, the dye removal efficiency falls down for both dyes. However, at IDC of Black 5 ranging from $30 \mathrm{mg} / \mathrm{L}$ to 50 $\mathrm{mg} / \mathrm{L}$, the decolorization efficient trends are more stable than other ranges. Whereas, for Blue 19, the suitable IDC is clear at $100 \mathrm{mg} / \mathrm{L}$. This trend may be due to restabilization phenomenon (Joo et al., 2007).

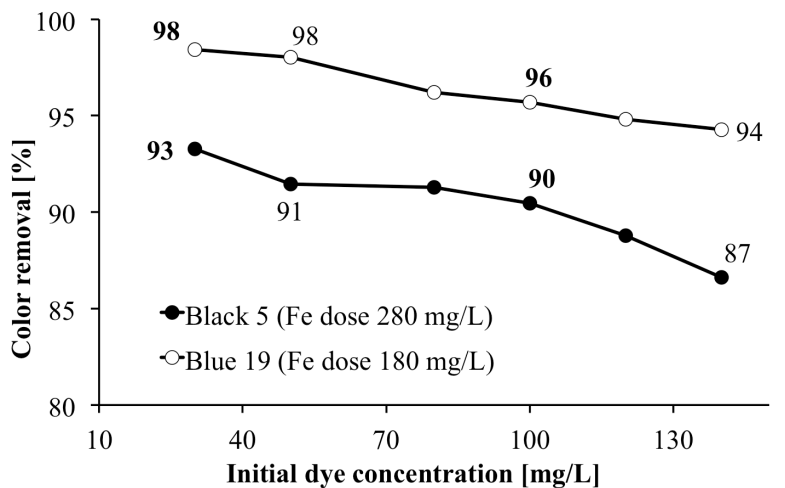

Figure 6. Effect of dye concentration on FAS coagulants (agitation speed $60 \mathrm{rpm}$, pH 12, and time $15 \mathrm{~min}$ )

\section{Conclusions}

Coagulation studies conducted on the two azonic reactive dyes (Blue 19 and Black 5) indicated that ferrous ammonium sulfate hexahydrate was capable to remove almost all the color (above 90\%) at lower dosages (180 and 280 $\mathrm{mg} / \mathrm{L}$ for Blue 19 and Black 5, respectively). The best removal rates were observed at $\mathrm{pH} 12$ and the optimum slow mixing speed was $60 \mathrm{rpm}$ during $15 \mathrm{~min}$. The high color removal may be explained by the electrostatic attraction of the anion dye and positive hydroxide form of ferrous soluble. Based on these results, FAS can be used as an efficient coagulant for color removal from reactive dye solution.

\section{References}

[1] Al-Mutairi, N.Z. 2006. Coagulant toxicity and effectiveness in a slaughterhouse wastewater treatment plant. Ecotox. Environ. Saf. 65(1): 74-83

[2] Alinsafi, A., Khemis, M., Pons, M.N., Leclerc, J. P., Yaacoubi, A., Benhammou, A., Nejmeddine, A. 2005. Electro-coagulation of reactive textile dyes and textile wastewater. Chem. Eng. Process. Process Intensif. 44(4): 461-470

[3] Arslan, I. 2001. Treatability of a simulated disperse dye-bath by ferrous iron coagulation, ozonation, and ferrous iron-catalyzed ozonation. J. Hazard. Mater. 85(3): 229-241

[4] ASTM, 2013. Standard practice for coagulationflocculation jar test of water. In annual book of ASTM standards, Vol. 11.02, United States: ASTM

[5] Carlos, B.-D., Manuel, P.-P., Mario, R.-R., Martinez, S. 2003. Chemical and electrochemical considerations on the removal process of hexavalent chromium from aqueous media. J. Appl. Electrochem. 33(1): 61-71

[6] Georgiou, D., Aivazidis, A., Hatiras, J., Gimouhopoulos, K. 2003. Treatment of cotton textile wastewater using lime and ferrous sulfate. Water Res. 37(9): 2248-2250

[7] Gottlieb, A., Shaw, C., Smith, A., Wheatley, A., Forsythe, S. 2003. The toxicity of textile reactive azo dyes after hydrolysis and decolourisation. J. Biotechnol. 110(1): 49-56

[8] Guida, M., Mattei, M., Della Rocca, C., Melluso, G., Meriç, S. 2007. Optimization of alumcoagulation/flocculation for COD and TSS removal from five municipal wastewater. Desalination 211(1-3): 113-127

[9] Joo, D.J., Shin, W.S., Choi, J.H., Choi, S.J., Kim, M.C., Han, M.H., Ha, T.W., Kim, Y.H. 2007. Decolorization of reactive dyes using inorganic coagulants and synthetic polymer. Dyes Pigm. 73(1): 5964

[10] Kim, T.-H., Park, C., Kim, S. 2005. Water recycling from desalination and purification process of reactive dye manufacturing industry by combined membrane filtration. J. Clean Prod. 13(8): 779-786

[11] Klimiuk, E., Filipkowska, U., Libecki, B. 1999. Coagulation of Wastewater Containing Reactive Dyes with the Use of Polyaluminium Chloride (PAC). Pol. J. Environ. Stud. 8(12): 81-88

[12] Lee, J.-W., Choi, S.-P., Thiruvenkatachari, R., Shim, W.-G., Moon, H. 2006. Submerged microfiltration membrane coupled with alum coagulation/powdered activated carbon adsorption for complete decolorization of reactive dyes. Water Res. 40(3): 435-444

[13] Perng, Y.S., Bui, H.M. 2014. The feasibility of cassia fistula gum with polyaluminium chloride for decolorization of reactive dyeing wastewater. J. Serb. 
Chem. Soc. 79(0): 1-26

http://dx.doi.org/10.2298/JSC140102041P

[14] Sadhasivam, S., Saritha, E., Savitha, S., Swaminathan, K. 2005. Comparison of the Efficacy of Live and Autoclaved Mycelium of Trichoderm harzianum on the Removal of Trypan Blue. Bull. Environ. Contam. Toxicol. 75(5): 1046-1053
[15] Shouli, A.S., Bewtra, J.K., Biswas, N. 1992. Effectiveness of coagulation and flocculation processes in removal of selected volatile organic contaminants from wastewaters. Int. J. Environ. Stud. 40(1): 27-40

[16] Tatsi, A.A., Zouboulis, A.I., Matis, K.A., Samaras, P. 2003. Coagulation-flocculation pretreatment of sanitary landfill leachates. Chemosphere 53(7): 737744 